\title{
Detection of residues of some heavy metals in fish fillets in Egyptian markets
}

\author{
R. H. Abdel-Dayem, H. M. Soltan, N. M.Marzouk \\ Department of Food Hygiene, Animal Health Research Institute, Dokki, Giza
}

\begin{abstract}
Fifteen samples of fish fillets were collected from different Egyptian markets to detect the residues of some heavy metals in them. The average weights of fish fillets samples were $250 \mathrm{~g}$. The samples were separately packed in polyethylene bag and sent to the laboratory for preparation and analysis. All equipment surfaces and utensils which used in this study were thoroughly cleaned with detergent, rinsed with water, dried and then rinsed with 2-propanol solution. The samples were stored at $-2^{\circ} \mathrm{C}$ prior to analysis. The mean levels of lead and cadmium in fish fillets collected from the Egyptian markets were $1.51 \pm 0.34$ and $0.60 \pm 0.0 .25 \mathrm{mg} / \mathrm{kg}$; respectively. The concentration of lead in fish muscle were less than the permissible heavy metal limit in fish meat $(2.0 \mathrm{mg} \mathrm{kg})$ as stated by the World Health Organization, also these results were in line with the corresponding EU regulations. However the level of cadmium concentration was over than the heavy metal limits in fish meat $(0.5 \mathrm{mg} / \mathrm{kg})$ for the World Health Organization.
\end{abstract}

Heavy metals such as cadmium and lead are common air pollutants and are emitted (predominantly into the air) as a result of various industrial activities WHO, (2007).

Many dangerous chemical elements, if they released into the environment, they were accumulated in the soil or sediments of water (Schuurmann and Markert 1998).

The low aquatic organisms absorb and transfer them through the food chain to higher trophic levels, including fish. Under acidic conditions, the free divalent ions of many metals may be directly absorbed by fish gills from the water (Part et al., 1985). Hence, concentrations of heavy metals (HM) in the organs of fish are primarily determined by the level of pollution of the water and feed (Farkas et al., 2000).

Heavy metal residues in fish flesh and its hazard effects on the health of people are a matter of great concern to food hygienists. The most non-essential heavy metals of particular concern to fish and surface water are cadmium (Cd) and lead $(\mathrm{Pb})$; which have the way to fish flesh mainly via gills (Tao et al., 1999; Tao et al., 2000).

Health safety is a very important aspect of food quality (Oledzka, 1999). Hazardous substances enter the food chain through the soil, air and water and are the main sources of contamination for humans. Heavy metals are among the most dangerous contaminants. In spite of more and more rigorous norms concerning their presence in food, and despite the introduction of quality assurance systems, it is impossible to get rid of them from food. Their presence in food is a result not only of the contamination of raw materials, but they can also originate from machines and industrial plants, food additives, and materials used in cleaning and disinfection procedures (Skibniewska, 2003). Recently, various dumps have become sources of serious environmental contamination. Very often they were built without due care which allowed leaks to occur from the deposits (Skibniewska et al., 2008). Every kind of waste, including pesticides, contains some quantity of heavy metals that can escape into the soil and ground water.

Contamination of fresh water fish with heavy metals is a recognized environmental problem. Increase in agricultural and industrial activities in an area directly influences the quality of water. In other words, water reservoirs are collectors of all materials spread by human industrial and agricultural activities. Heavy metals penetrate into water reservoirs via atmosphere, drainage, soil waters and soil erosion. As the concentration of heavy metals in the environment increases, the metals inevitably enter the biogeochemical cycle (Mansour and Sidky, 2002; Riget et al., 2004). Having contaminated water, Heavy metals accumulate in organisms, which are consumed by fish or directly penetrate into fish through skin and gills later (Sinha et al., 2002; Surec, 2003). 
Heavy metals cause the mutation of fish inner organs, disturbance of immune reactions, change blood parameters, reduce an organism's adaptation qualities, vitality, resistance to diseases, loss of fry and degeneration and diminution of valuable varieties of fish are observed as a result of heavy metals pollution (Alabaster and Lloydr, 1994; Blasco et al., 1999).

Use of agriculture and industry has been identified as a major source of wide dispersion into the environment and food. The major route of exposure to cadmium for the non-smoking general population is via food; the contribution from other pathways to total uptake is small (Goyer, 1991).

Lead pollution is multidimensional, including food processing techniques, traffic pollution and other factors. Lead poisoning is generally ranked as the most common environmental health hazard (Goyer, 1991). The most common routes of human lead exposure are inhalation of traffic exhaust fumes, inadvertent ingestion of lead paint and consumption of lead contaminated foods (Adekunle and Akinyemi, 2004). However, the uptake of lead through the food chain is of less importance since the concentration of lead in fish does not increase with trophic level and age but with increasing concentration in the water (Oehlenschlager, 2005).

Lead and cadmium are the most commonly distributed environmental metal poisons and each of these persistent contaminants has been blamed for large scale poisoning incidents. Several organizations such as Food and Agriculture Organization (FAO) and the World Health Organization (WHO) provide guidelines on the intake of trace elements by humans. The provisional tolerable weekly intake (PTWI) recommended by the Joint FAO/WHO Expert Committee for cadmium are $7 \mu \mathrm{g} / \mathrm{Kg}$ body weight per week (Anon, 2003) and $25 \mu \mathrm{g} / \mathrm{kg}$ body weight per week for lead (Anon, 1993).

Therefore, the aim of this study was to determine the concentration of lead and cadmium in fish fillets in different places in the Egyptian markets.

\section{Materials and methods}

Samples collection. Fifteen samples of fish fillets were collected from different markets in Egypt. The average weight of fish fillets samples was $250 \mathrm{~g}$. The samples were separately packed in polyethylene bag and sent to the laboratory for preparation and analysis. All equipment surfaces and utensils which used in this study were thoroughly cleaned with detergent, rinsed with water, dried and then rinsed with 2propanol solution. The samples were stored at $2^{\circ} \mathrm{C}$ prior to analysis.

Samples preparation for heavy metals (Cadmium and lead) residues. Cadmium and lead were determined according to AOAC (1996). Fish fillets was minced and well mixed, and then approximately $25 \mathrm{~g}$ were ignited in order to be converted into ash as a preliminary preparation for heavy metal analysis (ashing was carried out using muffle furnace at a temperature of $500 \mathrm{C}^{\mathrm{o}}$ overnight). To the ashed sample, 10 $\mathrm{ml}$ concentrated nitric acid were added with swirling. After a short soaking period, $5 \mathrm{~mL}$ of $60 \%$ perchloric acid were added and the mixture was slowly heated on a hot plate until the conclusion of growth (approximately $2 \mathrm{~h}$ ). The mixture was then heated until the appearance of dense white fumes that indicate the nitric acid had evaporated and perchloric acid had reached its boiling point. The mixture was cooled, $10 \mathrm{ml}$ of $25 \%$ hydrochloric acid were added and the solution was transferred to a $100 \mathrm{ml}$ volumetric flask that was subsequently brought to volume with deionized water. Assessment of metals level in prepared samples were carried out using an atomic absorption spectrophotometer (Model 3100, Perkin-Elmer, Norwalk, Conn , USA) operated under conditions given by EPA, (1994). Instruments parameters were: flow rate, $1.5 \mathrm{ml} / \mathrm{min}$; sample pump tube, $0.48 \mathrm{ml} / \mathrm{min}$; pump speed, 90 to $100 \mathrm{rpm}$; sample uptake time, 17 to $21 \mathrm{~s}$; flush time, $30 \mathrm{~s}$; integration time, $10 \mathrm{~s}$; wash time, 30s; background correction, on; and automatic blank subtraction, on. The low limits of detection were $0.10 \mathrm{ppm}$ for cadmium and $0.50 \mathrm{ppm}$ for lead.

\section{Results and discussion}

Table (1): Lead residues (ppm/wet weight) in fish fillets collected from Egyptian markets.

\begin{tabular}{lcccc}
\hline Item & Minimum & Maximum. & Mean \pm S.E & P.L.* \\
Fish fillets & 0.50 & 2.34 & $1.51 \pm 0.34$ & 2.00 \\
\hline
\end{tabular}

P.L.* = Permissible Limit (WHO, 1990 and 1993) 
Table (2): Cadmium residues (ppm/wet weight) in fish fillets collected from Egyptian markets.

\begin{tabular}{lcccc}
\hline Item & Minimum & Maximum. & Mean \pm S.E & P.L** \\
Fish fillets & 0.10 & 1.03 & $0.60 \pm 0.25$ & 0.50 \\
\hline
\end{tabular}

P.L.* = Permissible Limit (WHO, 1990 and 1993).

Table (3): Main routes of lead exposure and critical effects identified with associated Blood lead levels for various population groups (ATSDR 2005).

\begin{tabular}{|c|c|c|c|}
\hline Routes of intake & $\begin{array}{l}\text { Population } \\
\text { group (s) }\end{array}$ & Effects & Critical B-Pb ( $\mu \mathrm{g} / \mathrm{l})$ \\
\hline Placenta & Fetuses & Delays in neurological development & Probably no threshold \\
\hline \multirow{2}{*}{$\begin{array}{l}\text { Mother's milk, } \\
\text { Inhaled air, }\end{array}$} & \multirow{2}{*}{$\begin{array}{l}\text { Neonates and } \\
\text { young children }\end{array}$} & $\begin{array}{l}\text { Inhibition of } \delta \text {-aminolevulinic acid dehydratase } \\
\text { (an indicator of lead poisoning) }\end{array}$ & $30-300$ \\
\hline & & Physical development & $<70$ \\
\hline \multirow{5}{*}{$\begin{array}{l}\text { Inhaled air, } \\
\text { hand-mouth } \\
\text { behaviour, } \\
\text { ingestion }\end{array}$} & \multirow{5}{*}{ Children } & Decreased nerve conduction velocity & $200-300$ \\
\hline & & $\begin{array}{l}\text { Cognitive development and intellectual } \\
\text { performance }\end{array}$ & $<100$ \\
\hline & & Hearing loss & $<100$ \\
\hline & & Jaundice & 350 \\
\hline & & Anaemia & $>200$ \\
\hline \multirow{4}{*}{$\begin{array}{l}\text { Inhaled air, } \\
\text { food ingestion }\end{array}$} & \multirow{4}{*}{ Adults } & $\begin{array}{l}\text { Decreased } \delta \text {-aminolevulinic acid dehydratase } \\
\text { (an indicator of lead poisoning)activity }\end{array}$ & $30-340$ \\
\hline & & Blood pressure & $<20$ \\
\hline & & $\begin{array}{l}\text { Damage to renal function (decrease in } \\
\text { glomerular filtration rate) }\end{array}$ & $20-100$ \\
\hline & & Sperm count & $400-500$ \\
\hline
\end{tabular}

The concentrations of lead measured in fish fillets (Table 1) varied from 0.5 to $2.34 \mathrm{mg} / \mathrm{kg}$ with a mean value of $1.51 \pm 0.34 \mathrm{mg} / \mathrm{kg}$.

The obtained results for the concentration of lead in fish muscle were less than the maximum heavy metal limits in fish meat $(2.0 \mathrm{mg} / \mathrm{kg})$ for the World health Organization (1990, 1993), also these results were in line with the corresponding EU regulations (Anonymous, 2005). These findings were in agreement with results obtained by Ahmed and Hussein, (2004). Low results were obtained by Zyadah, (1999), Al-Shawafi, (2002), Suppin et al., (2005), Staniskiene et al., (2006);Tansel et al., (2006). High results were obtained by Mohamed and Abdel-Satar, (2005).

Health hazard characterization of lead. Lead is the well-studied toxic metal, and a wide range of biological effects dependent upon the level and duration of the exposure are known. The main health effects of lead exposure are summarized, together with routes of exposure, affected population groups and critical lead levels (Blood lead), in Table (3). Mortality in workers exposed to high levels of lead is increased, and adults who were poisoned by lead during childhood have increased blood pressure, which is a significant risk factor for cardiovascular diseases and mortality. Non-fatal mechanisms include renal effects; anaemia owing to the inhibition of several enzymes involved in haem synthesis; acceleration of skeletal maturation; alteration of hormone levels and immunity parameters. The encephalopathy (at high exposure) and various other diseases of the nervous system, among which cognitive and neurobehavioural deficits in children at low levels of exposure are of great concern. (ATSDR, 2005).

Table (2) showed the mean value of cadmium concentrations in analyzed samples which were $0.60 \pm 0.25$ with minimum value of $0.1 \mathrm{mg} / \mathrm{kg}$ and maximum value of $1.03 \mathrm{mg} / \mathrm{kg}$. These findings were over than the maximum heavy metal limits in fish meat $(0.5 \mathrm{mg} / \mathrm{kg})$ for the World Health Organization (1990, 1993). The obtained results were similar to the results recorded by Parsons, (1999); Ahmed and Hussein, (2004). High results were obtained by Mohamed \& Abdel-Satar, (2005); Vinodhini and Narayanan, (2008). Low parameters were obtained by Al-Shawafi, (2002); Suppin et al., (2005); Staniskiene et al., (2006).

Health hazard characterization of cadmium. Pulmonary absorption of inhaled cadmium ranges from $10 \%$ to $50 \%$ (WHO/ IPCS, 1992). 
The average normal gastrointestinal absorption of ingested cadmium in humans ranges from 3\% to $7 \%$. Cadmium in the tissues is mainly bound to metallothionein. The synthesis of this protein probably represented the body's defense mechanism against the toxic cadmium ion.

Liver and kidney tissues are the two main sites of cadmium storage. The newborn infant is virtually free of cadmium but, over a lifetime, these organs accumulate considerable amounts of cadmium (about $40-80 \%$ of the body burden) (WHO, 2007).

In low-level environmental exposures, about $30-50 \%$ of the cadmium body burden is stored in the kidneys. Cadmium elimination from blood has been described, as having a fast-decay halftime of 15-120 days and a slow-decay half-time of 7-16 years. Cadmium is eliminated in urine and faeces; daily faecal and urinary excretion is estimated to constitute $0.007 \%$ and $0.009 \%$ of the body burden, respectively (ATSDR, 1999).

Important health end points include kidney and bone damage and cancer. The kidney is the critical organ with regard to long-term occupational and environmental exposure to cadmium, and all health-based recommendations relate to the early disturbance of renal function. (ATSDR, 1999).

\section{Recommendations}

To safeguard the fish consumers, the periodical evaluation of heavy metals residual level in the fish flesh and water from expected polluted area are of major importance (Kock and Hofer, 1998; Medani and Ahmed, 1999).

\section{References}

Adekunle, I. M. and Akinyemi, M. F. (2004): Lead levels of certain consumer products in Nigeria: A case study of smoked fish foods from Abeokuta. Food and Chemical Toxicology, 42:1463-1468.

Ahmed, A. M. and Hussein, M. H. (2004): Residual levels of some heavy metals in fish flesh and water from El-Manzala Lake, Egypt. J. King Saud. Univ. 16: 187-196.

Alabaster, J. S. and Lloydr, R. (1994): Water quality criteria for freshwater fish. Food additives and Contaminants, 12: 25-38.

Al-Shawafi, N. A. A. (2002): Heavy metals concentration levels in some fish species in the Red Sea and Gulf of Aden-Yemen. Qater Univ. Sci. J. 22: 171-176.

Anonymous, (1993): Evaluation of certain food additives and contaminants. $41^{\text {st }}$ Report of Joint FAO/WHO, Committee on Food Additives, Geneva, Switzerland.

Anon, (2003): Joint FAO/WHO expert committee on food additives. Sixty-first Meeting Rome, June 10-19.

Anonymous, (2005): Commission Regulation (EC) No: 78/2005 of 16 January 2005 amending Regulation EC No: $466 / 2001$ as regards heavy metals. Official Journal L. 16/43. 20/1/2005, 43-45.

AOAC, (1996): "Official Methods of Analysis of the Association of Official Analytical Chemists". Method
975.03.B.b." In: Official Methods of Analysis of AOAC International, $16^{\text {th }}$ ed., V (1), Arlingoton (Va.): Section 3, pp 399-394.

ATSDR (1999): (Agency for Toxic Substances and Disease Registry), Toxicological profile for cadmium. Atlanta, GA, (http://www.atsdr. cdc.gov/toxprofiles/tp5.html).

ATSDR (2005): (Agency for Toxic Substances and Disease Registry), Draft toxicological profile for lead. Atlanta, GA, (http://www.atsdr.cdc.gov/toxprofiles/tp13. pdf, accessed 16 September 2007).

Blasco, J.; Arias, A.M. and Saenz, V. (1999): Heavy metals in organisms of the River Guadalquivir estuary: possible incidents of the Aznalcollar disaster. The Science of the Total Environment. 242, 249-262.

EPA, (1994): (Environmental Protection Agency) "Methods for the Determination of Metals in Environmental Samples- Supplement I, ICP EPA Method 200.7. EPA/600-R-111. May.” ORD Publications, USA.

Farkas, A.; Salánki, J. and Varanka, I. (2000): Heavy metal concentrations in fish of Lake Balaton. Lakes \& Reservoirs: Research and Management, 5: 271-279.

Goyer, R. A. (1991): Toxic effects of metals. In: Amdur. M.O. et.al (Eds.) Caserrett and Doull's Toxicology: The Basic Science of Poisons, $4^{\text {th }}$ ed. Pergamon Press, New York. pp: 623-680.

Kock, G. and Hofer, R. (1998): Origin of cadmium and lead in clear soft Water lakes of high-altitude and highlatitude, and their bioavailability and toxicity to fish. J. Exs., 86: 225-257.

Mansour, S. A. and Sidky, M. M. (2002): Heavy metals contaminating water and fish from Fayoum Governorate, Egypt. Food Chemistry, 78: 15-21.

Medani, G.G. and Ahmed, A.M. (1999): Cadmium, copper and lead residues in meat and edible offals of migratory quail at El-Manzala Lake. Suez Canal Vet. Med. J., 2: 373-385.

Mohamed, H. H. and Abdel-Satar, M. (2005): Studies of some heavy metals in water, sediment, fish and fish diet in some fish farms in el-Fayoum Province, Egypt. Egyptian J. Aquatic Research, 31: 261-273.

Oehlenschlager, J. (2005): Identifying heavy metals in fish. In: Safety and Quality Issues in Fish Processing. Bremner, H. A. Ed CRC Press LLC. pp. 95-108.

Oledzka, R. (1999): Current problems of the health safety of food, Farm. Pol., 23: 1083-1090.

Parsons, E. C. M.; Chan, H. M.; and Kinoshita, R. (1999): Organochlorine and trace metal concentrations in a Pygmy Bryde's whale (Balaenoptera edeni) from the South China Sea. Marine Pollution Bulletin, 38: 51-55.

Part, P.; Svanberg, O. and Kiessling, A. (1985): The availability of cadmium to perfused rainbow trout gills in different water qualities. Water Research, 19: 427-434.

Riget, F.; Dietz, R.; Vorka, M. P. K.; Johans, E. N. P. and Muir, D. (2004): Levels of spatial and temporal contaminants in Greenland biota: an updated review. Science of the Total Environment, 331: 29-40.

Schuurmann, G. and Markert, B. A. (1998): Ecotoxicology. Wiley and Sons, New York.

Sinha, A. K.; Gupta, P.; Barty, S.; Tacharyya, G. and Bhattachar, J. S. (2002): Bio-accumulation of heavy metals in different organs of some of the common edible fishes of Kharkai River, Jamshed pur. Indian. J. Environ. Health, 46: 102-112.

Skibniewska, K. A. (2003): Diet monitoring for the assessment of human exposure to environmental pollutants, Environ. Int., 28: 703-709. 
Skibniewska, K. A.; Guziur, J.; Marzec, Z.; Zaręba, S.; Grzybowski1, M. and Szarek, J. (2008): Lead and cadmium contents in the meat tissues of fish from water ecosystems in the vicinity of a pesticide tomb. Int. J. Oceanography and Hydrobiology, 3: 79-86.

Staniskiene, B.; Matusevicius, P.; Budreckiene, R. and Skibniewska, K.A. (2006): Distribution of Heavy Metals in Tissues of Fresh water Fish in Lithuania. Polish J. Environ. Stud. 15: 585-591.

Suppin, D.; Zahlbruckner, R.; Cermak, K.; Hauser, H. and Smulders, F. J. M. (2005): Mercury, lead and cadmium contents of fresh and canned fish collected from Austrian retail operations. Ernahrung nutrition, 11: 456460.

Surec, B. (2003): Accumulation of heavy metals by intestinal helmints in fish: an overview and perspective. Parasitology, 126: 53-65.

Tansel, S. U.; Goncuoglu, M.; Yildirım, Y.; Gucukog, A. and Cakmak, O. (2006): Assessment of heavy metals (cadmium and lead) in vacuum packaged smoked fish species (Mackerel, Salmo salar and Oncorhynhus mykiss) marketed in Ankara (Turkey). J. Fisheries and Aquatic Sciences, 23: 353-356

Tao, S., Liu, C.; Dawson, R.; Cao, J. and Li, B. (1999):

Uptake of particulate lead via the gills of fish (Carassius auratus). J. Arch. Environ. Contam. Toxicol., 3: 352-357.

Tao, S.; Liu, C.; Dawson, R.; Long, A. and Xu, F. (2000): Uptake of cadmium adsorbed on particulates by gills of goldfish (Carassius auratus). J. Ecotoxicol. Environ. Saf., 3: 306-313.

Vinodhini, R. and Narayanan, M. (2008): Bioaccumulation of heavy metals in fresh water fish Cyprinus carpio (Common carp). Int. J. Environ. Sci. Tech., 5: 179-182.

WHO (1990): "Guidelines for Seafood Quality." 2nd. ed., V (1), Recommendation, WHO Geneva.

WHO (1993): "Guidelines for Surface Water Quality." 2nd. ed.V(1), Recommendation, WHO Geneva.

WHO (2007): World Health Organization, "Health risks of heavy metals from long-range transboundary air pollution". WHO Regional Office for Europe Scherfigsve, 8 DK2100, Copenhagen O, Denmark.

WHO/IPCS (1992): World Health Organization. Cadmium, Geneva, (Envirovfdu plh] uf] hg]hdlnmental Health Criteria, No. 134 (http://www.inchem.org/ documents/ehc/ehc/ehc134.htm, accessed 11 September 2007).

Zyadah, M. A. (1999): Accumulation of some heavy metals in Tilapia zillii organs from lake Manzalah, Egypt. J. Zoology, 23: 365-372.

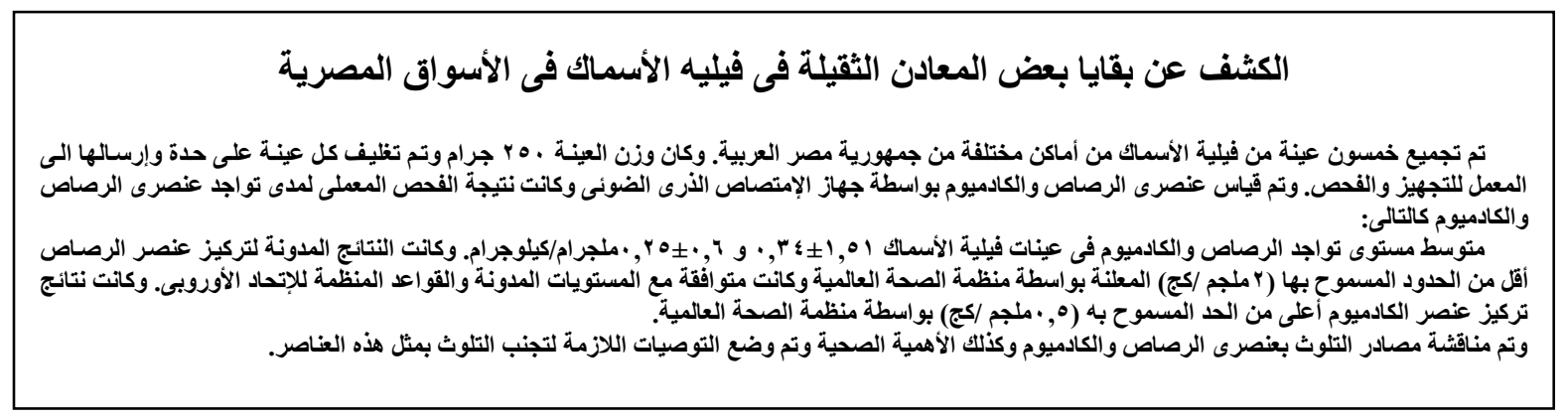

